\title{
Management of acute overdose or withdrawal state in intrathecal baclofen therapy
}

\author{
SV Watve ${ }^{1,2}$, M Sivan $^{1,2}$, WA Raza ${ }^{1}$ and FF Jamil ${ }^{1}$
}

Study design: Individuals who are treated with intrathecal Baclofen (ITB) pump delivery system for intractable spasticity can suffer from severe morbidity as a result of acute overdose or withdrawal of ITB, which can also be life threatening. Current literature has a number of single case studies with different approaches to the management in such states.

Objectives: The aim of this article is to consolidate available evidence and develop treatment pathways for acute ITB overdose and withdrawal states.

Methods: We searched MEDLINE, EMBASE, CINAHL and the Cochrane Library databases using the keywords 'intrathecal', 'baclofen', 'withdrawal', 'overdose' to identify studies (published up to December 2010) that focused on presentation or treatment of acute overdose and withdrawal state in ITB therapy. Only original articles in English involving adult population were included.

Results: Initial search revealed 130 articles. After reading the abstract, 13 studies on ITB overdose and 23 studies on ITB withdrawal were deemed suitable for inclusion. All studies were either single-case studies or case series.

Conclusion: Acute ITB overdose is managed with immediate cessation of baclofen delivery through the system, reducing the baclofen load by cerebrospinal fluid aspiration and by providing supportive treatment in an intensive care setting. There is no specific antidote for reversing overdose symptoms. Acute ITB withdrawal is managed by restoring the delivery of ITB, providing supportive care in an intensive care setting and using drugs like low dose propofol or benzodiazepines in selected cases. Early involvement of ITB physicians is strongly recommended.

Spinal Cord (2012) 50, 107-111; doi:10.1038/sc.2011.112; published online 18 October 2011

Keywords: Baclofen pump; spasticity; intrathecal; overdose; withdrawal

\section{INTRODUCTION}

Baclofen is considered to be the drug of choice for treating spasticity of spinal and cerebral origin. ${ }^{1}$ Baclofen is a synthetic derivative of the naturally occurring inhibitory neurotransmitter GABA ( $\gamma$-aminobutyric acid). At therapeutic doses, it acts principally on the $G_{A B A}$ receptors at the spinal/thalamic level, reducing the postsynaptic potentials along $\alpha$ motor neurons and thus relaxing the muscles. ${ }^{2}$

Oral baclofen does not effectively cross blood-brain barrier (being lipophobic) and hence some patients might need higher oral therapeutic doses to relieve spasticity. This unfortunately has serious systemic side effects. Patients who fail to respond to oral baclofen or who have significant side effects with it can benefit from Intrathecal Baclofen (ITB) delivered by a programmable implanted drug infusion system. ${ }^{3}$ This has the advantages of avoiding the systemic side effects and allowing a controlled delivery of baclofen. The precise delivery of ITB yields better spasticity control at 100 times lower dose than the oral dose of baclofen. ${ }^{4}$

The pump is implanted in the lower abdomen and dispenses medication from its reservoir through a silicon catheter into the thoraco-lumbar region intrathecally (Figure 1). Current available pumps are equipped with a catheter access port that bypasses the pump reservoir, permitting direct access to the intrathecal space via the catheter. The system is equipped with an alarm that signals low reservoir volume and low battery.

The above description of the ITB system is with reference to the system marketed by Medtronic Corporation. The readers should be aware that in the very near future there will be a number of other manufacturers of similar devices.

ITB is administered either in regular boluses and/or by continuous infusion. The daily dose needs adjustment with a programmer according to clinical effect and normally ranges from 50 to $1000 \mu \mathrm{g}$. As the drug is delivered into the cerebrospinal fluid (CSF) directly in the vicinity of $\mathrm{GABA}_{\mathrm{B}}$ receptors, patients are very sensitive to any change in the rate of drug delivery. This makes them susceptible to overdose and withdrawal states that can be life threatening. There have been numerous case series and single-case reports in literature on acute toxicity/withdrawal syndromes with use of various treatment methods. There is a need for a standardised protocol that can be used in emergency department, spinal injury and non-spinal injury units as a guide to manage these cases. In this article, we review all the available literature and recommend treatment pathways for both acute overdose/withdrawal syndromes.

\section{METHODS}

The authors SVW and MS conducted unrestricted searches in MEDLINE, EMBASE, PUBMED and COCHRANE databases through National library of health using the terms baclofen, intrathecal, acute, overdose and withdrawal, implant failure, catheter, and battery. From these searches, articles were selected for this review based on the following inclusion criteria:

1. Article reporting on either acute overdose or withdrawal from ITB therapy 2. Article involving adult population ( $>18$ years of age)

3. Article in English

${ }^{1}$ Yorkshire Regional Spinal Injuries Unit, Pinderfield Hospital, Wakefield, UK and ${ }^{2}$ Department of Rehabilitation Medicine, Leeds Teaching Hospitals NHS Trust, Leeds, UK Correspondence: FF Jamil, Department of Spinal Injuries, Pinderfield General Hospital, Aberford Road, Wakefield WF14DG, UK. E-mail: firas.jamil@midyorks.nhs.uk

Received 3 March 2011; revised 25 August 2011; accepted 27 August 2011; published online 18 October 2011 


\section{RESULTS}

From the initial searches of databases, 130 articles were identified. After reading the abstracts and applying the inclusion criteria, 13 articles on ITB overdose (29 patients) and 23 articles on ITB with-

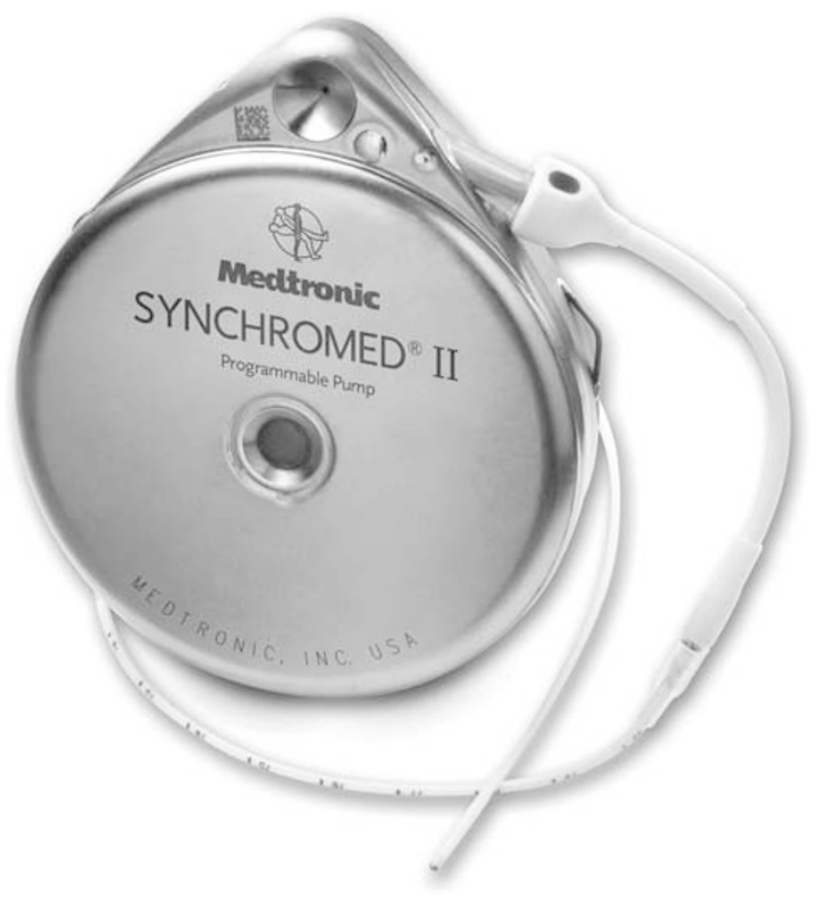

Figure 1 ITB delivery system (Acknowledgement: Medtronic). drawal (40 patients) were included. The methodology and results of the articles are summarised in Tables 1 and 2.

\section{DISCUSSION}

\section{Acute overdose}

The reviewed studies suggest that the overdose was closely associated with filling procedure/iatrogenic in 26 out of 29 patients. Among these 26 patients, in 14 the overdose occurred following refilling of the pump, in 6 following intrathecal bolus, in 2 during dose titration and in 4 other miscellaneous causes were noted. Pump malfunction was a possible cause in only 3 patients.

The symptoms manifest depending on the dose of baclofen being delivered. This includes hypotension, bradycardia/tachycardia, hypotonia, flaccid paralysis, somnolence, delirium, respiratory depression, seizures or cardiac abnormalities. ${ }^{5}$ Patients can deteriorate rapidly with the onset of profound respiratory depression/coma following overdose, needing emergency resuscitation. The main differential diagnoses are sepsis, intracranial bleed, hypoglycaemia, Cushing's triad and electrolyte imbalance.

Acute presentation needs emergency airway/breathing/circulatory support. We recommend that an experienced ITB physician is contacted as early as possible who can interrogate the pump and assess the situation. The ITB physician can stop the pump and in life-threatening cases, can drain CSF by lumbar puncture or by the access port of the pump. The treatment should be undertaken in an intensive care setting. Analysis of baclofen concentration in CSF obtained by lumbar puncture can provide valuable information about drug quantity administered specially in cases of inadvertent intrathecal bolus. An ITB physician can stop the pump for a limited period of $48 \mathrm{~h}$ only. After that, at least minimal rate should be used to prevent

Table 1 Articles on ITB overdose

\begin{tabular}{|c|c|c|c|}
\hline Author, year & $\begin{array}{l}\text { No. of } \\
\text { patients }\end{array}$ & Cause & Salient points \\
\hline $\begin{array}{l}\text { Muller-Schwefe et al. } \\
(1989)^{12}\end{array}$ & 3 & $\begin{array}{l}\text { One case of patient-administered bolus dose and two cases } \\
\text { of physician-administered bolus dose through pump. }\end{array}$ & $\begin{array}{l}\text { Physostigmine can be used for symptomatic management in baclofen } \\
\text { overdose. }\end{array}$ \\
\hline $\begin{array}{l}\text { Delhaas et al. } \\
(1991)^{13}\end{array}$ & 5 & Overdose during dose titration by physician. & $\begin{array}{l}\text { Lumbar puncture and drainage recommended. Physostigmine is not always } \\
\text { effective and safe. }\end{array}$ \\
\hline $\begin{array}{l}\text { Saltuari et al. } \\
(1992)^{14}\end{array}$ & 1 & Reservoir puncture during refill. & Increased risk of seizures to be borne in mind. \\
\hline Kofler et al. $(1992)^{15}$ & 1 & Bolus delivered during refill procedure. & $\begin{array}{l}\text { Ventilation needed in this case. Physostigmine, diazepam, phenytoin given } \\
\text { in management. }\end{array}$ \\
\hline $\begin{array}{l}\text { Dressnandt et al. } \\
(1996)^{16}\end{array}$ & 1 & Air sucked in while refilling. & $\begin{array}{l}\text { Use of a three-way stopcock during emptying and refilling of reservoir } \\
\text { recommended. }\end{array}$ \\
\hline $\begin{array}{l}\text { Fakhoury et al. } \\
(1998)^{17}\end{array}$ & 1 & Intrathecal injection of baclofen instead of reservoir. & $\begin{array}{l}\text { EEG abnormalities without seizures, don't need use of anti-epileptic treat- } \\
\text { ment. }\end{array}$ \\
\hline $\begin{array}{l}\text { Rushman et al. } \\
(1998)^{18}\end{array}$ & 1 & Pump malfunction. & Physostigmine not useful in management. CSF aspiration recommended. \\
\hline Byrnes et al. (1996) 19 & 1 & Reactivation of pump following repair of pump system. & Flumazenil ineffective in management. \\
\hline Plassat et al. $(2004)^{1}$ & 3 & Related to pump refilling procedure. & $\begin{array}{l}\text { Severe pharmacological side effects requiring transfer to intensive care unit, } \\
\text { occurred in all } 3 \text { cases. }\end{array}$ \\
\hline Tunali et al. $(2005)^{20}$ & 1 & Pump malfunction. & $\begin{array}{l}\text { Baclofen pump filling should be performed in an advanced hospital with } \\
\text { an ITU facility. CSF drainage is the most effective treatment in management. }\end{array}$ \\
\hline Dalton et al. $(2008)^{21}$ & 1 & $\begin{array}{l}\text { Inability to override miscalculation of dead space } \\
\text { between reservoir and catheter access port. }\end{array}$ & $\begin{array}{l}\text { Correction to be made for the 'dead space' between the reservoir and } \\
\text { catheter access port while reprogramming. }\end{array}$ \\
\hline $\begin{array}{l}\text { Castaño et al. } \\
(2009)^{22}\end{array}$ & 8 & Overdose following first filling or refill. & ITB overdose can cause agitation, drowsiness and disorientation. \\
\hline Teddy et al. $(1992)^{23}$ & 2 & $\begin{array}{l}\text { After implantation, intrathecal bolus delivered } \\
\text { by pump. }\end{array}$ & $\begin{array}{l}\text { Pump implantation recommended in limited centres by experienced sur- } \\
\text { geons and close monitoring after procedure. }\end{array}$ \\
\hline
\end{tabular}

Abbreviations: CSF, cerebrospinal fluid; EEG, electroencephalography; ITB, intrathecal baclofen; ITU, intensive treatment unit. 
Table 2 Articles on ITB Withdrawal

\begin{tabular}{|c|c|c|c|}
\hline Author, year & $\begin{array}{l}\text { No. of } \\
\text { patients }\end{array}$ & Cause & Salient points \\
\hline $\begin{array}{l}\text { Siegfried et al. } \\
(1992)^{24}\end{array}$ & 1 & Programming error. & Accurate calculation/measurement during refill recommended. \\
\hline $\begin{array}{l}\text { Khorasani et al. } \\
(1995)^{25}\end{array}$ & 1 & Infected pump removal. & Dantrolene can be effective in symptomatic management. \\
\hline $\begin{array}{l}\text { Reeves et al. } \\
(1998)^{26}\end{array}$ & 1 & Catheter failure. & High dose benzodiazepines can be used in treatment. \\
\hline $\begin{array}{l}\text { Alkhodairy et al. } \\
(1999)^{27}\end{array}$ & 1 & Distal catheter leak/withdrawal, cut catheter. & $\begin{array}{l}\text { Careful postoperative monitoring/attention needed. Avoid heavy physical } \\
\text { activity to avoid catheter misplacement. }\end{array}$ \\
\hline $\begin{array}{l}\text { Sampathkumar } \\
\text { et al. }(1998)^{28}\end{array}$ & 1 & Catheter break. & Clinical presentation may mimic severe infection. \\
\hline $\begin{array}{l}\text { Green et al. } \\
(1999)^{29}\end{array}$ & 1 & Pump malfunction. & Intrathecal bolus of baclofen used in management. \\
\hline $\begin{array}{l}\text { Greenberg et al. } \\
(2003)^{30}\end{array}$ & 1 & Pump removal. & $\begin{array}{l}\text { Oral baclofen alone cannot be relied for treatment of withdrawal. It is advisable } \\
\text { to combine benzodiazepine. }\end{array}$ \\
\hline $\begin{array}{l}\text { Pasquier et al. } \\
(2003)^{31}\end{array}$ & 1 & Subdural catheter migration. & CT scan after contrast injection can be used to localise distal catheter tip. \\
\hline $\begin{array}{l}\text { Bardutzky et al. } \\
(2003)^{32}\end{array}$ & 1 & Catheter leak. & $\begin{array}{l}\text { Patients presenting with persistent systemic symptoms, particularly those who } \\
\text { are febrile, must be investigated for acute baclofen withdrawal. }\end{array}$ \\
\hline $\begin{array}{l}\text { Santiago-Palma } \\
\text { et al. }(2004)^{33}\end{array}$ & 1 & Leak at the junction of the pump and the catheter. & $\begin{array}{l}\text { Onset of dyspnoea associated with hypertonia should prompt the investigation } \\
\text { of baclofen withdrawal. }\end{array}$ \\
\hline $\begin{array}{l}\text { Mohammed et al. } \\
(2004)^{34}\end{array}$ & 1 & Programming error. & $\begin{array}{l}\text { Patient education, pump restoration, treatment with high dose benzodiaze- } \\
\text { pines, ITU care. }\end{array}$ \\
\hline $\begin{array}{l}\text { Pizon et al. } \\
(2007)^{35}\end{array}$ & 1 & latrogenic weaning for side effects. & ITB withdrawal can cause reversible cardiomyopathy. \\
\hline $\begin{array}{l}\text { Fernandes et al. } \\
(2008)^{10}\end{array}$ & 1 & Catheter cut during dissection for posterior spinal fusion. & $\begin{array}{l}\text { Patient and surgeon should be aware of possibility of catheter trauma during } \\
\text { spinal surgery in patients with ITB pump. }\end{array}$ \\
\hline $\begin{array}{l}\text { Martens et al. } \\
(2009)^{36}\end{array}$ & 1 & Catheter retraction during suprapubic cystostomy. & $\begin{array}{l}\text { Specific attention should be paid to the positioning of these patients during any } \\
\text { surgery, avoiding a reduction in lordosis of the lumbar spine might help to } \\
\text { prevent catheter retraction. }\end{array}$ \\
\hline $\begin{array}{l}\text { Bellinger et al. } \\
(2009)^{9}\end{array}$ & 1 & Infected pump removal. & $\begin{array}{l}\text { Temporary externalised intrathecal catheter followed by tapering infusion/ } \\
\text { replacement with oral antispasmodics used in management. }\end{array}$ \\
\hline $\begin{array}{l}\text { Ross et al. } \\
(2010)^{7}\end{array}$ & 1 & Catheter protruding out of skin. & $\begin{array}{l}\text { Reinstitution of ITB as soon as possible. Benzodiazepines/propofol infusions } \\
\text { helpful. }\end{array}$ \\
\hline $\begin{array}{l}\text { Coffey et al. } \\
(2002)^{6}\end{array}$ & 6 & $\begin{array}{l}\text { Programming error, end of battery life, catheter } \\
\text { disconnection/kinking and empty reservoir. }\end{array}$ & $\begin{array}{l}\text { GABAergic agonist drugs, Dantrolene infusion, high-dose benzodiazepine } \\
\text { infusion can be used in treatment. }\end{array}$ \\
\hline $\begin{array}{l}\text { Meythaler et al. } \\
(2003)^{37}\end{array}$ & 4 & $\begin{array}{l}\text { Catheter kink, pump stalling, position dependent catheter } \\
\text { narrowing, pump removal for overlying skin infection. }\end{array}$ & Cyproheptadine may be a useful adjunct to baclofen and benzodiazepines. \\
\hline $\begin{array}{l}\text { Rigoli et al. } \\
(2004)^{38}\end{array}$ & 2 & Low residual volume. & Pump could be programmed to alarm at $3 \mathrm{ml}$ residual volume. \\
\hline $\begin{array}{l}\text { Duhon et al. } \\
(2007)^{8}\end{array}$ & 2 & Catheter migration, Stopped pump. & $\begin{array}{l}\text { External lumbar drain and a standard patient-controlled analgesia pump (in } \\
\text { continuous infusion mode) can be used to administer ITB during withdrawal. }\end{array}$ \\
\hline $\begin{array}{l}\text { Ackland et al. } \\
(2005)^{11}\end{array}$ & 2 & Pump failure, catheter position. & $\begin{array}{l}\text { Propofol can be used in management, Ashworth spasticity scale can be used as } \\
\text { outcome. }\end{array}$ \\
\hline $\begin{array}{l}\text { D'Aleo et al. } \\
(2007)^{2}\end{array}$ & 2 & Battery exhaustion, Stopped pump. & ITB bolus injection and oral baclofen can be used in management. \\
\hline $\begin{array}{l}\text { Castaño et al. } \\
(2009)^{22}\end{array}$ & 4 & End of battery life, empty pump reservoir. & Clinical presentation can be confusion with hallucinations. \\
\hline
\end{tabular}

Abbreviations: CT, computer tomography; ITB, intrathecal balcofen.

damage to the pump. Before restarting the pump, concentration of drug in the tubing and catheter needs to be taken to account to avoid complications of further overdose.

There is no specific antidote for ITB overdose. Most patients with overdose recover completely with adequate supportive care (intravenous fluids, ventilation support etc). There have been a few case reports suggesting intravenous Physostigmine for symptomatic relief, but we do not recommend its use as it has significant side effects with doubtful properties as an antidote.

\section{Acute withdrawal}

Studies suggest that patients experience withdrawal symptoms close to their scheduled refill dates and $40 \%$ are because of catheter-related problems. The following are the other causes; infected pump removal, empty reservoir volume, end of battery life and iatrogenic programming error. In total, seven deaths were noted in all cases reviewed in this article.

Rebound spasticity is the earliest symptom and can be associated with tachycardia, fever leading to hyperthermia, itching or seizures. 


\section{ACUTE BACLOFEN OVERDOSE}

Fever itself can produce increased spasticity, whereas in ITB withdrawal primary presentation is increased spasticity, which can be associated with fever. For physicians who are not familiar with this condition, diagnosis may not be suspected and can be easily missed.

Patients can have neuropsychiatric symptoms such as hallucinations, delirium, delusions and paranoia as well. In the most severe cases, malignant hyperthermia, autonomic instability, rhabdomyolysis, diffuse intravascular coagulopathy and multi-organ system failure can occur. Reports in the reviewed literature are mostly about presentation with severe symptoms. Cases with milder symptoms are known to occur in clinical practice, but may be under-reported and data about what percentage of these patients progress to severe symptoms is lacking.

The differential diagnosis of ITB withdrawal includes autonomic dysreflexia (bradycardia with hypertension, lack of rebound spasticity), malignant hyperthermia (after anaesthesia, familial disorder), serotonergic syndrome (selective serotonin reuptake inhibitor (SSRI) overdose, myoclonus, raised liver function tests), neuroleptic malignant syndrome (use of dopamine blocking neuroleptic drugs or abrupt withdrawal dopamine agonist), sepsis and meningitis. ${ }^{6,7}$

We recommend that an experienced ITB physician is contacted as early as possible who can interrogate the pump to provide information about pump function and amount of baclofen in the pump reservoir. If there is reasonable reservoir volume, the catheter continuity needs to be investigated. $\mathrm{X}$ abdomen (AP/Lat) can provide information about catheter position. A catheterogram (a dye study of catheter system) can be done to check continuity. Surgical exploration of pump may be needed to restore catheter continuity/replacement of pump as indicated. This depends on the patient's medical condition.

Externalised intrathecal catheter can been used to reinstitute ITB delivery in life-threatening cases. There have been reports of temporary infusion of ITB in three cases in reviewed literature. ${ }^{8,9}$ In these patients, indwelling lumbar intrathecal catheter was placed and infusion of baclofen was setup at pre-withdrawal doses. Baclofen was diluted with preservative-free saline in the infusion. In two cases, standard patient-controlled analgesia pump was used because of its capacity to deliver small volumes.

Oral baclofen as a rescue medication is not effective as it does not achieve high enough CSF levels and hence is not reliable to treat this condition. There have been cases when even $160 \mathrm{mg}$ per day have not been effective. ${ }^{10}$ One study showed a 100 -fold decrease in CSF concentrations when comparing a $50 \mathrm{mcg}$ ITB bolus and a $30 \mathrm{mg}$ oral baclofen dose. ${ }^{7}$ In selected cases where restoration of ITB was not possible, therapy with other drugs that have similar pharmacological properties like propofol and benzodiazepines have been considered for symptomatic relief.

Benzodiazepines act on $\mathrm{GABA}_{\mathrm{A}}$ and hence their action is not affected by downregulation of $\mathrm{GABA}_{\mathrm{B}}$ receptors occurring in chronic ITB infusion. They also have advantage of sedative and anti-epileptic action. ${ }^{6}$ Propofol is another agent acting on $\mathrm{GABA}_{\mathrm{A}}$ receptors. Advantages of its use include rapid action, short half-life allowing titratability with symptoms. It also has anti-inflammatory/anti-nociceptive properties. ${ }^{7,11}$ It can only be used in a neurocritical unit. There is lack of sufficient clinical evidence for using dantrolene or cyproheptadine for withdrawal symptoms (also cyproheptadine is not available in all countries).

\section{RECOMMENDATIONS}

Recommendations for management of acute overdose are shown in Figure 2. These patients should be closely monitored for withdrawal symptoms after the pump has been stopped and continuously
Diagnosed from history / features - hypotonia, flaccid paralysis, somnolence, delirium, hypotension, respiratory depression, seizures

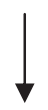

\section{Airway / Breathing / Circulation}

(Consider ITU admission)

Systemic examination / lab investigations to rule out other causes

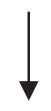

ITB physician to stop pump (max. $48 \mathrm{hrs}$ )/ replace reservoir with saline

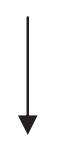

In severe cases, withdraw CSF as much as possible by lumbar puncture (fluoroscopic guidance can be used if available)

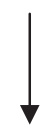

\section{Continue supportive care (Intensive monitoring) ITB physician to restart pump within $48 \mathrm{hrs}$ from stopping}

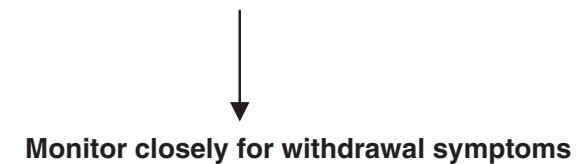

Figure 2 Management of ITB overdose.

monitored. Recommendations for management of acute withdrawal are shown in Figure 3.

\section{General recommendations}

1. Patient and carers should be educated about functioning of the pump, recognition of the symptoms of overdose or withdrawal.

2. They should have $24 \mathrm{~h}$ access to the ITB physician.

3. The institutional caregivers, paramedical staff and non-ITB physicians should be made aware through education to identify these problems.

4. Patients should ideally have bracelets with drug dose, physician and manufacturer's contact details.

5. Further research is needed to find specific antidote to baclofen.

6. Training of physicians involved in managing these devices needs to be improved through training workshops. Baclofen refill procedures should be done in dedicated clinic.

The studies included in this review were case reports or case series. Our recommendations in this article are based on analysis of these studies and hence lack the highest quality of evidence level. However, it might be extremely difficult to conduct a randomised 


\section{ACUTE BACLOFEN WITHDRAWAL}

Diagnosis from history and features like rebound spasticity tachycardia, fever leading to hyperthermia, itching, paresthesias or seizures

High index of suspicion if presenting around refill date

\section{Airway / Breathing / Circulation}

(ITU admission)

Systemic examination/ Investigations to rule out other causes

Contact ITB physician

ITB physician can check pump status / aspirate the reservoir/ and/or administer bolus dose ITB in severe cases

Externalised intrathecal catheter can be used if available

Abdomen X-ray and Catheterogram to investigate catheter continuity

In severe cases - high dose benzodiazepines infusion or low dose propofol infusion (limited evidence for both treatments)

(Until ITB dose restored)

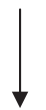

\section{Continued supportive inpatient care}

Monitor closely for serious complications like

rhabdomyolysis, Disseminated Intravascular Coagulation (DIC)

Figure 3 Management of ITB withdrawal.

controlled trial because of the low incidence of these acute states encountered in ITB practice.

\section{CONCLUSION}

Patients with ITB pump are always at risk of serious events like acute ITB overdose/withdrawal. Majority (90\%) of overdose states are directly related to refill procedures and can be easily avoided. Most $(40 \%)$ of withdrawal states are due to catheter problems and need investigation of catheter continuity. Both overdose and withdrawal can be successfully treated if recognised early and treated appropriately.

\section{CONFLICT OF INTEREST}

The authors carried out Synchromed (by Medtronic) intrathecal pump implantation. No external grants have been received for writing this article.

1 Plassat R, Perrouin Verbe B, Menei P, Menegalli D, Mathe JF, Richard I. Treatment of spasticity with intrathecal Baclofen administration: long-term follow-up, review of 40 patients. Spinal Cord. 2004; 42: 686-693.

2 D'Aleo G, Cammaroto S, Rifici C, Marra G, Sessa E, Bramanti P et al. Hallucinations after abrupt withdrawal of oral and intrathecal baclofen. Funct Neurol. 2007; 22: 81-88.

3 Sadiq SA, Wang GC. Long-term intrathecal baclofen therapy in ambulatory patients with spasticity. J Neurol. 2006; 253: 563-569.
4 Penn RD, Kroin JS. Long-term intrathecal baclofen infusion for treatment of spasticity. J Neurosurg. 1987; 66: 181-185.

5 Leung NY, Whyte IM, Isbister GK. Baclofen overdose: defining the spectrum of toxicity. Emerg Med Australas. 2006; 18: 77-82.

6 Coffey RJ, Edgar TS, Francisco GE, Graziani V, Meythaler JM, Ridgely PM et al. Abrupt withdrawal from intrathecal baclofen: recognition and management of a potentially lifethreatening syndrome. Arch Phys Med Rehabil. 2002; 83: 735-741.

7 Ross JC, Cook AM, Stewart GL, Fahy BG. Acute intrathecal baclofen withdrawal: a brief review of treatment options. Neurocrit Care. 2010; 14: 103-108.

8 Duhon BS, MacDonald JD. Infusion of intrathecal baclofen for acute withdrawal. Technical note. J Neurosurg. 2007; 107: 878-880.

9 Bellinger A, Siriwetchadarak R, Rosenquist R, Greenlee JD. Prevention of intrathecal baclofen withdrawal syndrome: successful use of a temporary intrathecal catheter. Reg Anesth Pain Med. 2009; 34: 600-602.

10 Fernandes P, Dolan L, Weinstein SL. Intrathecal baclofen withdrawal syndrome following posterior spinal fusion for neuromuscular scoliosis: a case report. lowa Orthop J. 2008; 28: 77-80.

11 Ackland GL, Fox R. Low-dose propofol infusion for controlling acute hyperspasticity after withdrawal of intrathecal baclofen therapy. Anesthesiology. 2005; 103: 663-665.

12 Muller-Schwefe G, Penn RD. Physostigmine in the treatment of intrathecal baclofen overdose. Report of three cases. J Neurosurg. 1989; 71: 273-275.

13 Delhaas EM, Brouwers JR. Intrathecal baclofen overdose: report of 7 events in 5 patients and review of the literature. Int J Clin Pharmacol Ther Toxicol. 1991; 29: 274-280.

14 Saltuari L, Marosi MJ, Kofler M, Bauer G. Status epilepticus complicating intrathecal baclofen overdose. Lancet. 1992; 339: 373-374.

15 Kofler M, Saltuari L, Schmutzhard E, Berek K, Baumgartner H, Russegger L et al. Electrophysiological findings in a case of severe intrathecal baclofen overdose. Electroencephalogr Clin Neurophysiol. 1992; 83: 83-86.

16 Dressnandt J, Weinzierl FX, Tolle TR, Konstanzer A, Conrad B. Acute overdose of intrathecal baclofen. J Neurol. 1996; 243: 482-483.

17 Fakhoury T, Abou-Khalil B, Blumenkopf B. EEG changes in intrathecal baclofen overdose: a case report and review of the literature. Electroencephalogr Clin Neurophysiol. 1998; 107: 339-342.

18 Rushman S, McLaren I. Management of intra-thecal baclofen overdose. Intensive Care Med. 1999; 25: 239.

19 Byrnes SM, Watson GW, Hardy PA. Flumazenil: an unreliable antagonist in baclofen overdose. Anaesthesia. 1996; 51: 481-482.

20 Tunali Y, Hanimoglu H, Tanriverdi T, Hanci L, Hanci M. Intrathecal baclofen toxicity and deep coma in minutes. J Spinal Cord Med. 2006; 29: 237-239.

21 Dalton C, Keenan E, Stevenson V. A novel cause of intrathecal baclofen overdosage: lessons to be learnt. Clin Rehabil. 2008; 22: 188-190.

22 Castano B, Benito J, Pires F, Ferreira S, Lopez R, Vidal J. Delirium secondary to intrathecal baclofen. Spinal Cord. 2009; 47: 477-480.

23 Teddy P, Jamous A, Gardner B, Wang D, Silver J. Complications of intrathecal baclofen delivery. Br J Neurosurg. 1992; 6: 115-118.

24 Siegfried RN, Jacobson L, Chabal C. Development of an acute withdrawal syndrome following the cessation of intrathecal baclofen in a patient with spasticity. Anesthesiology. 1992; 77: 1048-1050.

25 Khorasani A, Peruzzi WT. Dantrolene treatment for abrupt intrathecal baclofen withdrawal. Anesth Analg. 1995; 80: 1054-1056.

26 Reeves RK, Stolp-Smith KA, Christopherson MW. Hyperthermia, rhabdomyolysis, and disseminated intravascular coagulation associated with baclofen pump catheter failure. Arch Phys Med Rehabil. 1998; 79: 353-356.

27 Al-Khodairy AT, Vuagnat H, Uebelhart D. Symptoms of recurrent intrathecal baclofen withdrawal resulting from drug delivery failure: a case report. Am J Phys Med Rehabil. 1999; 78: 272-277.

28 Sampathkumar P, Scanlon PD, Plevak DJ. Baclofen withdrawal presenting as multiorgan system failure. Anesth Analg. 1998; 87: 562-563.

29 Green LB, Nelson VS. Death after acute withdrawal of intrathecal baclofen: case report and literature review. Arch Phys Med Rehabil. 1999; 80: 1600-1604.

30 Greenberg MI, Hendrickson RG. Baclofen withdrawal following removal of an intrathecal baclofen pump despite oral baclofen replacement. J Toxicol Clin Toxicol. 2003; 41: 83-85.

31 Pasquier Y, Cahana A, Schnider A. Subdural catheter migration may lead to baclofen pump dysfunction. Spinal Cord. 2003; 41: 700-702.

32 Bardutzky J, Tronnier V, Schwab S, Meinck HM. Intrathecal baclofen for stiffperson syndrome: life-threatening intermittent catheter leakage. Neurology. 2003; 60: $1976-1978$

33 Santiago-Palma J, Hord ED, Vallejo R, Trella J, Ahmed SU. Respiratory distress after intrathecal baclofen withdrawal. Anesth Analg. 2004; 99: 227-229.

34 Mohammed I, Hussain A. Intrathecal baclofen withdrawal syndrome- a life-threatening complication of baclofen pump: a case report. BMC Clin Pharmacol. 2004; 4: 6.

35 Pizon AF, Lovecchio F. Reversible cardiomyopathy complicating intrathecal baclofen withdrawal: a case report. J Med Toxicol. 2007; 3: 187-189.

36 Martens FM, Somford DM, van Kuppevelt DH, van den Burg MJ, Heesakkers JP. Retraction of an intrathecal baclofen infusion catheter following suprapubic cystotomy: a case report. J Rehabil Med. 2009; 41: 90-91.

37 Meythaler JM, Roper JF, Brunner RC. Cyproheptadine for intrathecal baclofen withdrawal. Arch Phys Med Rehabil. 2003; 84: 638-642.

38 Rigoli G, Terrini G, Cordioli Z. Intrathecal baclofen withdrawal syndrome caused by low residual volume in the pump reservoir: a report of 2 cases. Arch Phys Med Rehabil. 2004: 85: 2064-2066. 